\title{
Climate change and the Viking-age fjord environment of the Eastern Settlement, South Greenland
}

\author{
Antoon Kuijpers, Niels Abrahamsen, Gerd Hoffmann, Veit Hühnerbach, Peter Konradi, Helmar Kunzendorf, \\ Naja Mikkelsen, Jörn Thiede, Wilhelm Weinrebe and shipboard scientific party of RV Poseidon, \\ and surveyors of the Royal Danish Administration for Navigation and Hydrography
}

The main objective of the project reported here is to reconstruct late Holocene hydrographic changes in South Greenland fjords and to study the relationship with large-scale atmospheric climate change; in particular to shed light on a possible link between these hydro- graphic changes and the disappearance of the Norse from Greenland more than five centuries ago. The project (1998-2000) is financially supported by the Danish Natural Science Research Council and the Government of Greenland.
Fig. 1. Map of the Norse Eastern Settlement, with location of the study areas (red) in the innermost part of Tunulliarfik and Igaliku Fjord; the present towns of Qaqortoq/Julianehåb and Nanortalik are shown. The location of core PO 243-451 is also indicated. Black dots are ruins or sites related to the Norse period. Crosses indicate church ruins. The inset map shows the regional setting of the study area, the location of Iceland with the capital Reykjavik. The Inland Ice is not shown.

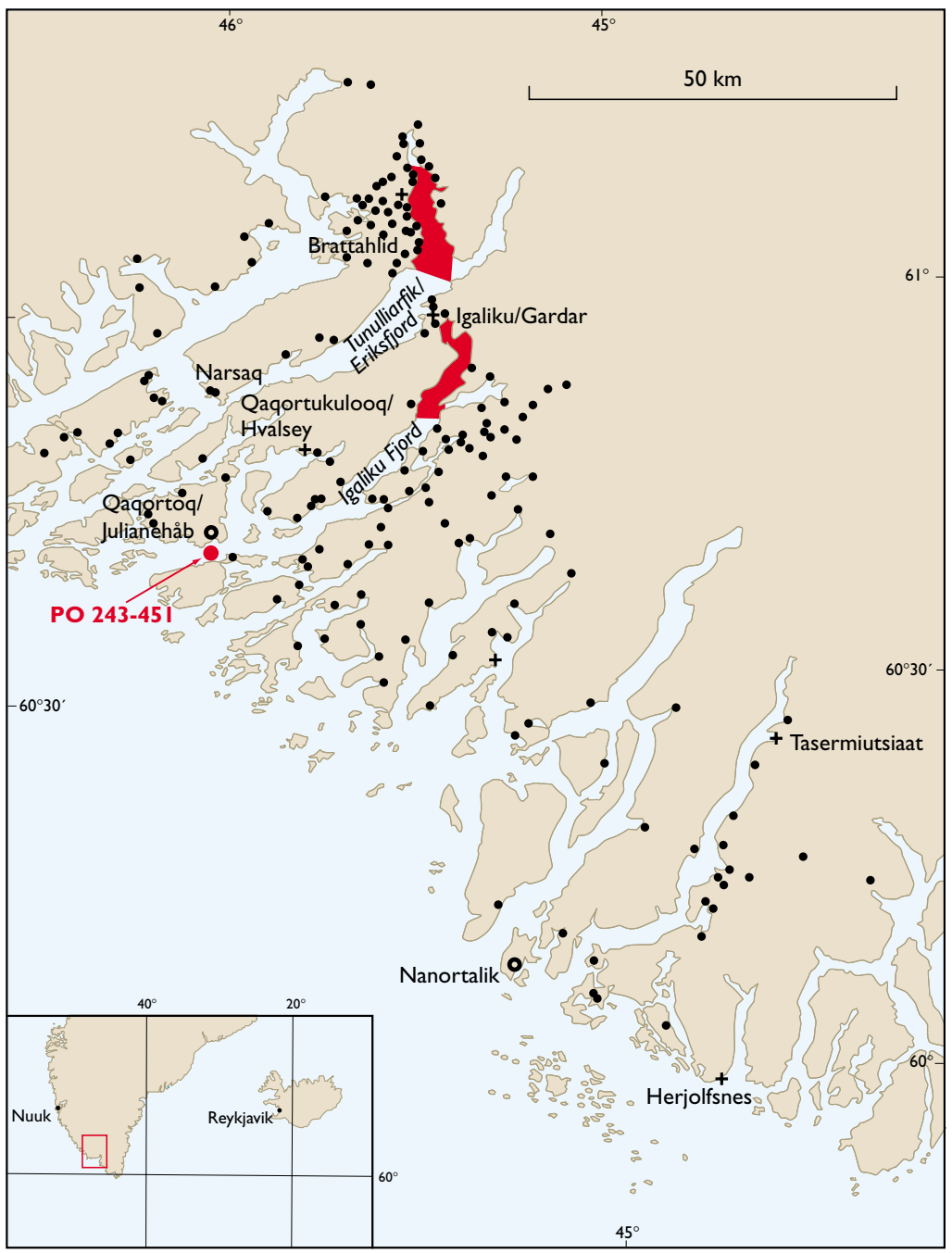


From the 'Grønlændersaga' and confirmed by historical and archaeological evidence we know that a Norse colony (for location, see Fig. 1) was founded in South Greenland in AD 985 by Eric the Red and other settlers from Iceland. Despite a large number of studies undertaken onshore in the area of the Eastern Settlement, the ultimate cause for the loss of the settlement almost 500 years later has not yet been determined. Amongst the explanations proposed for the disappearance of the Norse population, researchers have invoked climatic change, decline of shipping trade with Iceland and Europe, raids by European pirates, competition with immigrating Inuits, and disease.

From Mediaeval Icelandic sources we know that after the first period of colonisation, sea ice off south-eastern Greenland had significantly expanded, causing growing problems to Norse shipping between Iceland and Greenland. Numerous indications have been found in the northern hemisphere pointing to severe climate deterioration between about AD 1350 and AD 1850 (Little Ice Age), following the end of the Mediaeval Warm Period or Climatic Optimum (c. AD 900-1350). As described by Dansgaard et al. (1989), cold climate conditions revealed by the ice core records from central Greenland were characterised by dry and very stormy weather conditions, providing further evidence for adverse sailing conditions. Further evidence for more stormy weather also having affected the coastal areas of Greenland, particularly during the winter months, has recently come from studies carried out in North-East Greenland (Christiansen 1998). Stuiver et al. (1995) found in their study of the GISP2 Greenland ice core that Little Ice Age cold conditions prevailed between c. AD 1350 and 1800, with the extremes of low temperature dated at AD 1720. They dated the Mediaeval Climatic Optimum peak at AD 975, i.e. close to the time of the Norse 'landnám' in South Greenland. It is emphasised here, that due to their location the climate records from the central Greenland ice cores cannot resolve all low-altitude climatic changes of the more maritime domaines of Greenland. As an example, the Greenland Summit ice cores GISP2 and GRIP reveal a remarkably stable Holocene climate compared to the glacial record. However, records from smaller ice caps more exposed to (Arctic) ocean climate at lower altitudes, e.g. Hans Tausen Iskappe, eastern North Greenland, and the Devon and Agassiz ice caps in the Canadian Arctic Archipelago, clearly demonstrate substantial climatic changes within the Holocene.

Until now, however, there was no firm evidence for a causal link between the Little Ice Age climate deteri- oration and the loss of both the Western and Eastern Settlements. The latter was notably able to survive for several generations after the beginning of the Little Ice Age.

It may be relevant here to note that while modern global average annual temperature has been steadily rising since the beginning of the 1980s, over the last decade a significant cooling trend has been observed in the West Greenland temperature records (Danish Meteorological Institute, unpublished data). In addition, Greenland ice core measurements indicate decreasing temperatures over central Greenland during the last few decades (Dahl-Jensen et al. 1998). Thus, northern hemisphere climatic trends can display large regional differences, which may also have applied to the various Little Ice Age stages.

\section{Project concept}

With the background information referred to above, it was envisaged that a better understanding of the disappearance of the Norse from the Eastern (and Western) Settlements might be achieved by studying the possible impact of the Little Ice Age on the fjord waters surrounding the settlements. It is evident, that for shipping and food supply these waters have been of crucial importance for the survival of the settlement. Major regional hydrographic changes, such as a more extensive or semi-permanent ice cover, can be assumed to have had major consequences for the fjord flora and fauna, and, therefore, for the standing stocks available for hunting and fishing. Such changes would also have had a negative effect on shipping. In a broader sense, such palaeo-hydrographic studies will add to our knowledge of the regional oceanographic impact induced by large-scale climatic change.

The project was launched through the initiative of the Geological Survey of Denmark and Greenland (GEUS) in co-operation with the Research Center for Marine Geosciences (GEOMAR) in Kiel, Germany. Close collaboration with the National Museum of Denmark in Copenhagen and Roskilde, and the National Museum and Archive of Greenland in Nuuk was obvious. A collection of sediment cores from the bottom of the fjords was considered to be essential. In order to locate the most suitable locations for coring, a shallow seismic survey was a pre-requisite. Use of the relevant acoustic techniques also included deep-tow side-scan sonar in order to be able to trace possible underwater cultural 
heritage sites such as shipwrecks, lost cargo, constructions or other items.

Deployment of deep-tow side-scan sonar equipment at 200-300 m water depth, and more generally, navigation by a large research vessel, can only be undertaken when basic bathymetric data are available. Since this information was not available for the fjords under investigation, the involvement of the Royal Danish Administration for Navigation and Hydrography (Farvandsvæsenet) was necessary for carrying out the project. Finally, the deployment of a Remote Operated Vehicle (ROV) was foreseen as part of the work at sea to investigate possible acoustic targets.

\section{Shipboard studies with RV Poseidon}

The research cruise with RV Poseidon (Cruise 243) was carried out between 24 August and 10 September, 1998, with Reykjavik as the logistic port for the start and end

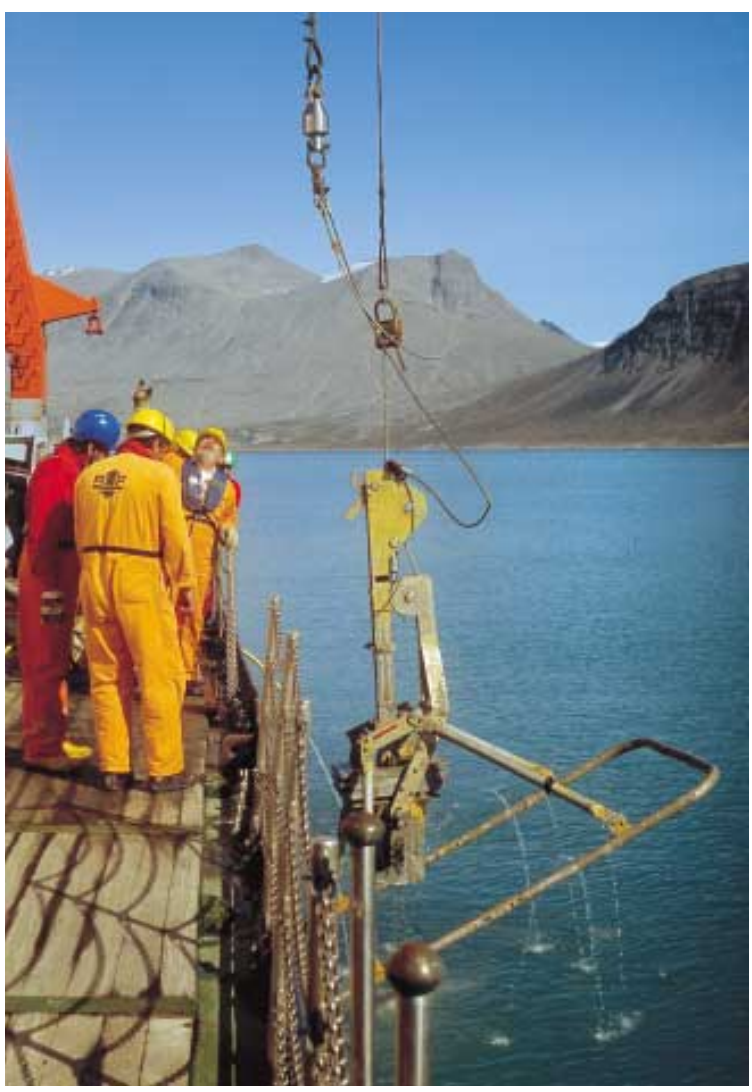

Fig. 2. Retrieval of a box core during sediment sampling operations in Igaliku Fjord. of the cruise. Scientists from GEUS, GEOMAR, the Greenland National Museum, the Alfred Wegener Institute for Polar and Marine Research, Bremerhaven, Germany, the Norwegian University of Science and Technology, Trondheim, the University of Iceland, and from the Southampton Oceanography Centre, United Kingdom, were involved. On transit to and from South Greenland gale-force winds were encountered, which resulted in delays of about 24 hours both ways.

Upon arrival in the study area off Julianehåb, on 29 August, a rendezvous was arranged with the two hydrographic survey vessels of the Royal Danish Administration of Navigation and Hydrography, during which the newly acquired results from the bathymetric mapping of the study areas (Fig. 1) were handed over by the commanding officers of the survey vessels to the Master of RV Poseidon. In addition, useful information on relevant navigational aspects was received, and RV Poseidon was escorted by the survey vessels to its working area at the head of Igaliku Fjord. During the entire survey

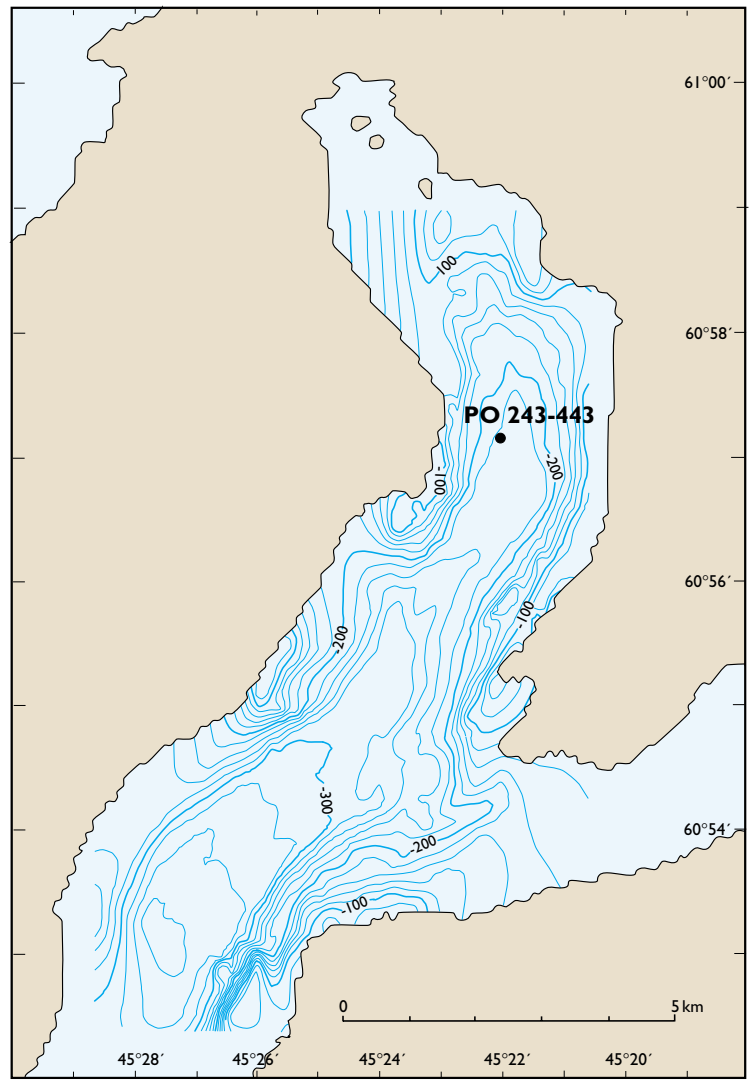

Fig. 3. Bathymetry of the innermost part of Igaliku Fjord obtained with the ELAC multi-beam bottom charting system. The site of core PO 243-443 is shown. For location see Fig. 1. 
period favourable weather conditions prevailed (Fig. 2), and ice conditions in Tunulliarfik did not adversely affect the progress of the work.

Both in Igaliku Fjord and in Tunulliarfik a combination of side-scan sonar, hull-mounted ELAC multi-beam bottom charting system, hull-mounted $18 \mathrm{kHz}$ echo-sounder, and a towed, high-resolution CHIRP sub-bottom profiler system were used. In most parts of the survey areas a deep-tow EG \& G $(59 \mathrm{kHz})$ side-scan sonar system (Kiel University, Germany) was deployed, but in the shallow coastal zone ( $<10 \mathrm{~m}$ water depth), which was surveyed by rubber boat, a $100 \mathrm{kHz}$ Klein side-scan sonar driven by batteries was used. Upon completion of the acoustic survey, several objects detected by side-scan sonar, and some additional sites, were investigated by the Remote Operated Vehicle.

In order to obtain sediment samples with an undisturbed surface, a Reineck box corer (Fig. 2) and a $6 \mathrm{~m}$ long gravity corer were deployed. With the newly acquired acoustic sub-bottom information it can be concluded that the seabed in both fjords is nearly everywhere characterised by the presence of mass flow and turbidite deposits. Only a few sites were found suitable for coring with the aim of collecting sediments for high resolution palaeo-hydrographic studies. In addition to a number of box cores, a total of seven gravity cores were collected in Igaliku Fjord, and four gravity cores were obtained from Tunulliarfik. An additional gravity core was taken off Qaqortoq/Julianehåb (Fig. 1). Two gravity cores, one from the Igaliku Fjord study area (Fig. 3), and one at the entrance to the fjord near Julianehåb, proved to be of good quality, and were selected for further laboratory analyses.

\section{Post-cruise laboratory analyses}

Immediately after the cruise, samples taken from the box cores were transported to the Ris $\varnothing$ National Laboratory for ${ }^{210} \mathrm{~Pb}$ and ${ }^{137} \mathrm{Cs}$ measurements in order to determine recent (last 150 years) accumulation rates. The samples were also analysed for their general geochemical composition. A number of box and gravity cores were measured for magnetic susceptibility, and palaeomagnetic measurements were carried out on the two suitable gravity cores. The latter cores were also subsampled for high resolution geochemical studies (Risø National Laboratory, Denmark). In addition, several horizons were selected for AMS ${ }^{14} \mathrm{C}$ datings to be carried out at the Aarhus University, Denmark dating facility (J. Heinemeier).
Detailed microfossil studies will be undertaken in 1999, in part within the framework of a Ph.D. study to be carried out at the Geological Survey of Denmark and Greenland in Copenhagen and financed by the special North Atlantic Research Program of the Danish Research Agency.

\section{Preliminary results}

\section{Coastal drowning}

Various indications show that after mid-Holocene times the initial glacio-isostatic rebound of Greenland was followed by increased subsidence, resulting in a relative sea-level rise (e.g. Rasch \& Fog Jensen 1997). This subsidence is well documented by the semi-inundation of the Norse graveyard of Herjolfsnes, about 100 $\mathrm{km}$ to the south-east of the study area (Fig. 1), and the drowning of Inuit ruins of late Holocene age.

During our shallow water side-scan sonar survey in Tunulliarfik off Brattahlid, the site where Eric the Red settled, a drowned beach was recorded (Fig. 4). After correction for the tidal factor, the level of this drowned beach was shown to be 3 to $4 \mathrm{~m}$ below mean sea level. Although no material could be sampled for dating, an age not much in excess of 1000 years BP is envisaged. This is based on the results of the dating of a desiccation horizon at about $9 \mathrm{~m}$ below sea level in a core from Narsaq harbour, $30 \mathrm{~km}$ to the south-west (Fig. 1). The age of this horizon is $3080{ }^{14} \mathrm{C}$ years BP (A. Weidick, personal communication 1999), indicating a relative sea level stand at that time of at least $10 \mathrm{~m}$ below the present level. Thus, it is concluded, that the average late Holocene relative sea-level rise is in the order of about (at least) $3 \mathrm{~m}$ per 1000 years. This implies that during the 500 years of the Norse settlement era large areas of the fertile lowlands along the fjords were drowned. For example, at the drowned beach zone off Brattahlid (see Figs 1, 4), the relative sea-level rise probably resulted in coastal regression over a distance of more than $100 \mathrm{~m}$ for the last c. 1000 years. In particular, off the former episcopal residence of Gardar at the northernmost end of Igaliku Fjord, where at present large areas of the fjord are less than $5 \mathrm{~m}$ deep, a gradual loss of useful land areas due to the relatively fast sea-level rise must have had a destructive effect on the farming and (grass) cultivation potential of the successive Norse generations in the area. 


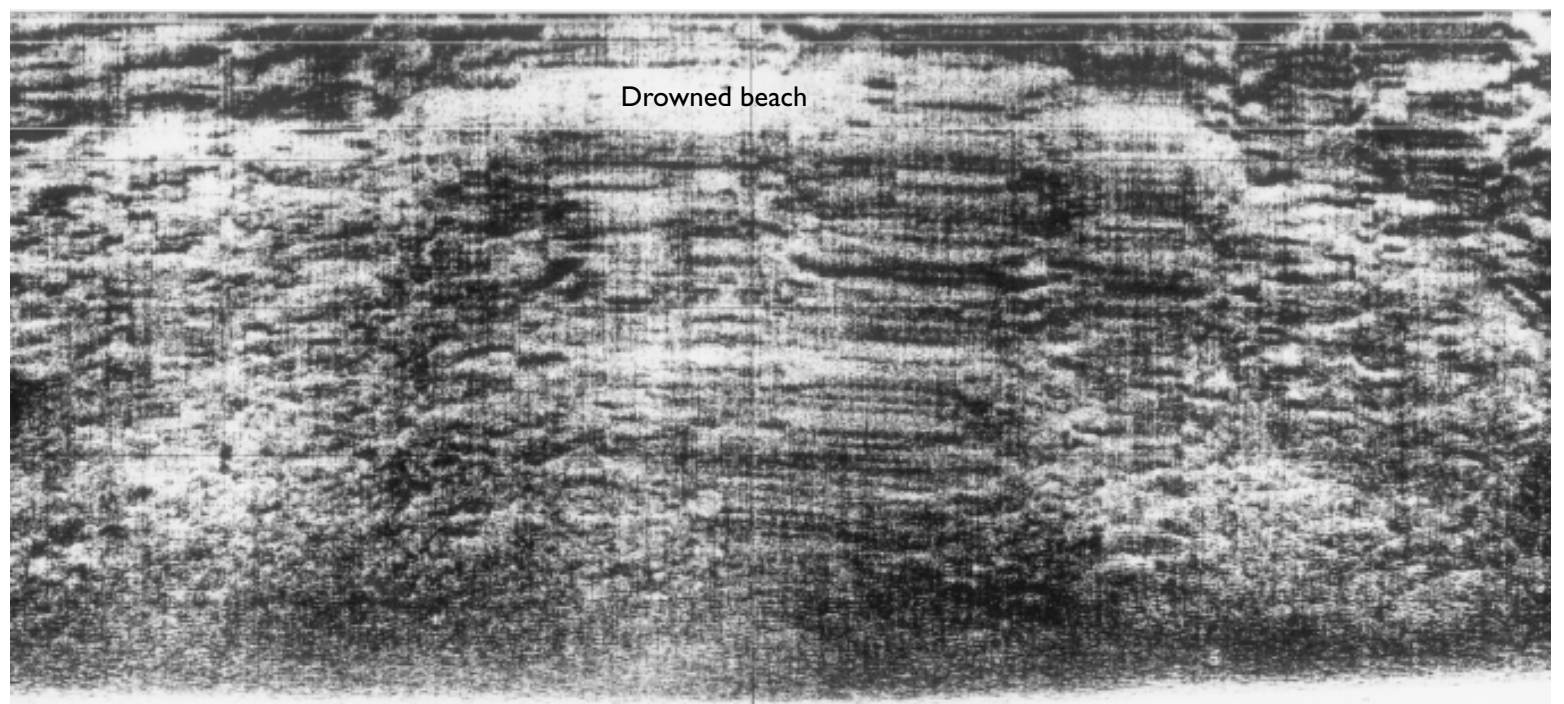

\section{$\mathbf{N}$}

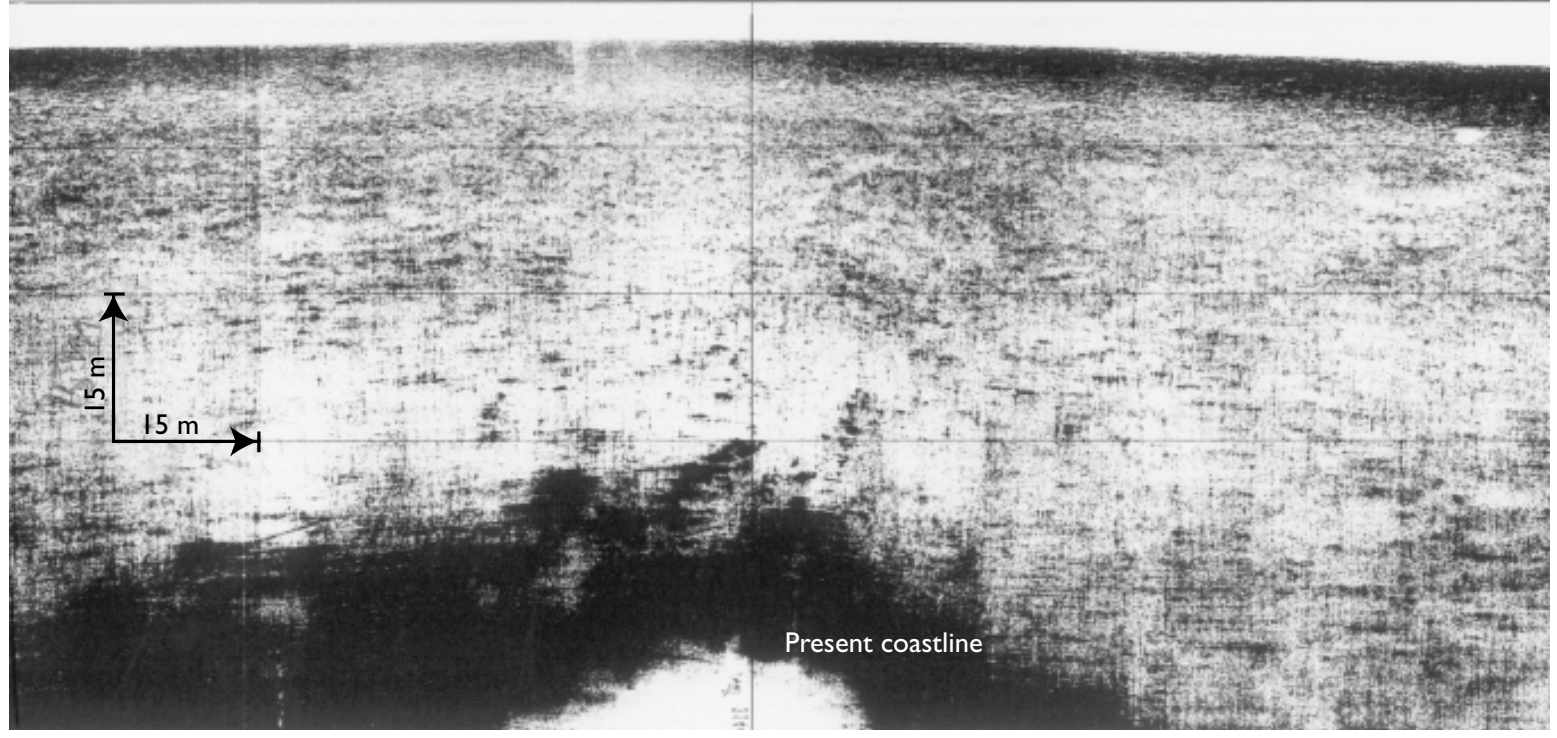

Fig. 4. Side-scan sonar record obtained on a coast-parallel track in shallow waters off Brattahlid. The record shows a drowned beach (white band) at 3-4 m below present mean sea level, at about $110 \mathrm{~m}$ distance from the present coastline.

\section{Regional submarine sedimentary disturbances}

As outlined above, the subbottom profiler information from most parts of Tunulliarfik and Igaliku Fjord indicates the widespread occurrence of downslope sediment transport processes. Consequently, sediments from the deeper parts of the fjords frequently contain coarsergrained (sand, gravel) material derived from debris flow and turbidity current processes. Additional input of sand and gravel can be ascribed to occasional ice rafting. The seabed sonar imagery data show that in Tunulliarfik reworking of the seabed due to iceberg ploughing was much more widespread than in Igaliku Fjord. The maximum water depth where iceberg plough marks were observed is about $80 \mathrm{~m}$.

The core PO 243-443 from Igaliku Fjord (Fig. 5a) was collected at one of the rare sites where the sub- 
Core PO 243-443

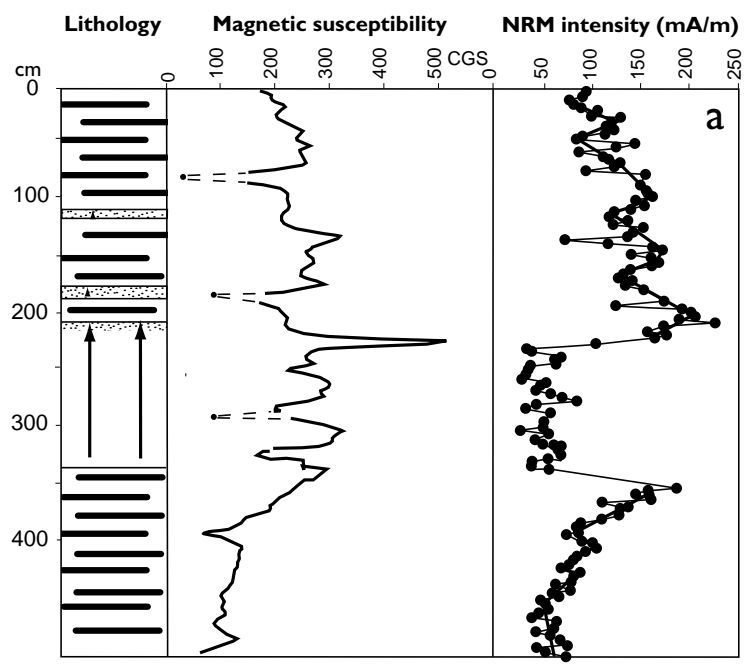

Core PO 243-45 I

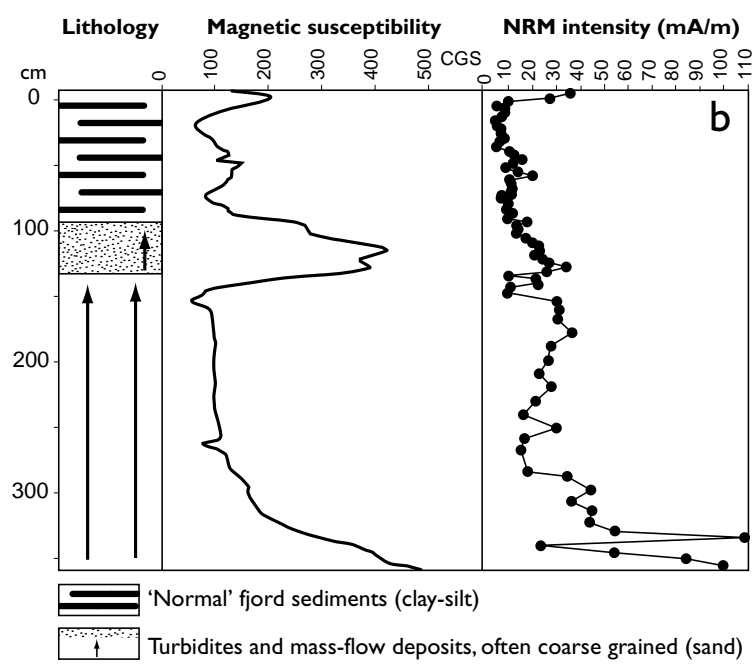

Fig. 5. Simplified lithological log with magnetic susceptibility profile (whole core measurements) and natural remanent magnetisation (NRM) intensity of $\mathbf{a}$ : core PO 243-443 and $\mathbf{b}$ : core PO 243-451. The magnetic properties generally reflect the lithological differences of the mass flow and turbidite units, when compared with the sediment intervals indicative of more quiet (normal) fjord sedimentation. Isolated magnetic susceptibility minima (see dashed line, core PO 243-443) presumably originate from measurement failure or disturbed sediment.

bottom profiler information indicated a sedimentary sequence not much affected by late Holocene sediment mass flow processes. The location of the site is shown in Fig. 3.

A box core (PO 243-430) was taken at the same site for which recent sedimentation rates were determined by ${ }^{210} \mathrm{~Pb}$ and ${ }^{137} \mathrm{Cs}$ measurements. Results from these measurements indicate an average linear sedimentation rate of about $20 \mathrm{~cm}$ for the last 100 years. Both the lithological log of core PO 243-443 and that of core PO 243-451 (Fig. 5b) taken near Julianehåb show that relatively quiet sedimentary conditions prevailed during the time of deposition of the upper metre of silty clay and clayey silt. A preliminary estimate based on the ${ }^{210} \mathrm{~Pb}$ information from core $\mathrm{PO} 243-443$, suggests that the latter conditions may have been characteristic of the past $c .500$ years.

Palaeomagnetic data show a declination record (not given here) with a westerly deflection, which in core PO 243-443 is confined within the 0.4-2.0 m interval. Such a westerly deflection is also found in core PO $243-451$, where it is present within the upper metre of sediment. From historic and palaeomagnetic records from South Greenland and North-West Europe it is known that the declination was systematic to the west between $\mathrm{AD}$ 1600 and 1900. Within this context, it is interesting to refer to the magnetic susceptibility profile of core PO 243-443 (Fig. 5a), which displays markedly low values in the lowermost part of the core below $350 \mathrm{~cm}$ depth. In this part of the core sediments are, as in the upper metre, indicative of a normal, relatively quiet sedimentary environment, whereas the intermediate interval below about $110 \mathrm{~cm}$, and more particularly below $175 \mathrm{~cm}$ subbottom depth, is characterised by the repeated occurrence of mass flow deposits which also includes coarser material. The natural remanent magnetisation (NRM) records shown in Fig. 5 clearly illustrate these differences in sediment type. The reason for significantly lower magnetic susceptibility values near the bottom of the core must be sought in sedimentary and physico-chemical conditions that were different from those prevailing in the period of sedimentation of the silty and clayey sediments of the top unit. Tentatively, it is concluded that climate conditions governing the fjord hydrography and the more regional (onshore) sedimentary processes must have been different, i.e. most likely characterised by higher temperatures than those of the Little Ice Age that followed.

Thus, although firmer conclusions must await the first results from the AMS ${ }^{14} \mathrm{C}$ measurements, we suggest that sedimentary conditions in the area have been relatively stable during the last 500 years or so. The same 
applies to the conditions prevailing during the Mediaeval Climatic Optimum. However, submarine sliding and slumping may have occurred frequently during the transition from one climate regime to the other, i.e. at the beginning of the Little Ice Age. Increased submarine slope instability during that time may be linked to the effect of generally intensifying atmospheric circulation, most likely resulting in more frequent storm surges with increased shallow water wave-action and sediment reworking. At shallow water depths seabed reworking by grounded ice may also have intensified. Enhanced niveo-fluvial sedimentary processes onshore may have additionally contributed to a larger sediment input to the fjords, thus further destabilising (overloading) the slope sediments. The latter processes may apply in particular to the study areas in the inner parts of the fjords.

However, more puzzling, and highly interesting with respect to the regional scale of the environmental changes observed, is the thick ( $>2 \mathrm{~m}$ ), extremely finegrained and homogeneous turbidite unit found below $135 \mathrm{~cm}$ subbottom depth in core PO 243-451 (Fig. 5b). Although the base of the unit was not cored, the increased magnetic susceptibility values at the bottom of the core clearly indicate increasing grain sizes with depth, or a larger content of (titano-magnetite) heavy minerals, suggesting the presence of the base of the turbidite unit just below. The lithology of the deposit demonstrates an extremely distal setting. The core is located in a small trough in the central part of the fjord, with a direct connection to more open shelf waters not far away to the south-west. Therefore, we cannot exclude that fast turbidite sedimentation here could also have originated from an extreme sedimentation event triggered on the shelf. Further ongoing and planned analyses will certainly contribute to a better characterisation of the latter sedimentary processes.

In summary, it appears that various large-scale sediment disturbances have occurred both at the entrance and in the innermost part of Igaliku Fjord. Preliminary results from ${ }^{210} \mathrm{~Pb}$ measurements and palaeomagnetic information suggest that these events were initiated at the beginning of the Little Ice Age. The results of AMS ${ }^{14} \mathrm{C}$ measurements currently being carried out at Aarhus
University, Denmark will hopefully enable a more accurate timing of these sediment mass flow events to be determined in the course of the year.

\section{Acknowledgements}

We acknowledge the financial support from GEOMAR, the Alfred Wegener Institute for Polar and Marine Research, Germany, the Danish Natural Science Research Council, research funds from the Government of Greenland and the Geological Survey of Denmark and Greenland. The Norwegian University of Science and Technology (Marek Jasinski and Fredrik Søreide), Trondheim, contributed with ROV expertise and technical assistance, whereas the ELAC Company (Kiel, Germany) provided a multi-beam bottom charting system. The cruise would not have been possible without the excellent collaboration of the Royal Danish Administration for Navigation and Hydrography. Sediment coring and acoustic work was successfully carried out owing, amongst others, to the skills of the marine engineers Peter Trøst Jørgensen (GEUS) and Thorsten Schott (Geo Marine Service, Rickert, Germany). Insights into Greenlandic history were provided by Emil Rosing, the Director of the Greenland National Museum and Archive, who joined the cruise. Last, but not least, the Master of RV Poseidon, Martin Kull, and his crew are thanked for their constant efforts during the work at sea.

We thank Anker Weidick (GEUS) for his useful comments on an earlier version of our manuscript.

\section{References}

Christiansen, H.H. 1998: 'Little Ice Age' nivation activity in northeast Greenland. The Holocene $\mathbf{8}(6), 719-728$.

Dahl-Jensen, D., Mosegaard, K., Gundestrup, N., Clow, G.D., Johnsen, S.J., Hansen, A.W. \& Balling, N. 1998: Past temperatures directly from the Greenland Ice Sheet. Science $\mathbf{2 8 2}$, 268-271.

Dansgaard, W., White, J.W.C. \& Johnsen, S.J. 1989: The abrupt termination of the Younger Dryas climate event. Nature 339, 532-534.

Rasch, M. \& Fog Jensen, J. 1997: Ancient Eskimo dwelling sites and Holocene relative sealevel changes in southern Disko bugt, central West Greenland. Polar Research 16(2), 101-115.

Stuiver, M., Grootes, P.M. \& Braziunas, T.F. 1995: The GISP2 $\delta^{18} \mathrm{O}$ climate record of the past 16,500 years and the role of the sun, ocean, and volcanoes. Quaternary Research 44, 341-354.

\footnotetext{
Authors' addresses:

A.K., P.K. \& N.M., Geological Survey of Denmark and Greenland, Thoravej 8, DK-2400 Copenhagen NV, Denmark. E-mail: aku@geus.dk N.A., Department of Earth Sciences, University of Aarbus, Finlandsgade 8, DK-8200 Aarbus N, Denmark. G.H. \& W.W., GEOMAR Research Center for Marine Geosciences, Wischbofstrasse 1-3, D-24148 Kiel, Germany. V.H., Southampton Oceanography Centre, Challenger Division, Empress Dock, Southampton SO143ZH, UK.

H.K., Risø National Laboratory, PO Box 49, DK-400O Roskilde, Denmark.

J.T., Alfred Wegener Institute for Polar and Marine Research, Columbusstrasse, D-27568 Bremerhaven, Germany.
} 